\title{
THE EFFECT OF FREEZING ON CEMENT MORTAR AND CONCKETE
}

By C. E. Bowman, B. S. IN C. E. (Class of 1899)

At the present time there is hardly a structure of any considerable proportions into which cement does not enter as a building material, and it is unquestionable that had we a more accurate knowledge of its properties and behavior under various conditions, and more reliable methods of testing, its use and adaption would at cnce be increased many fold. To ascertain the strength and properties under perfectly normal laboratory conditions has so far baffled engineering skill. To the end of discovering or deducing a method by which two or more testers may obtain the same results from the same cement under conditions that are as near alike as can be obtained, the American Society of Civil Engineers has now at work a committee of experts selected from its members. This committee, after having been out for over two years, reported progress in January, I900, and was continued. Societies of other countries have also had committees at work on this same problem for a longer period.

It is, then, not surprising that there should be much doubt and many widely diverging opinions concerning the effect on cement of the widely varying conditions met with in practice. Of these numerous conditions there is probably none concerning which there is more doubt, and justly so, than on the effect of freezing on cement. Opinions, based largely on the results of experiments and practice, range all the way from the conviction that to freeze cement while it is setting always damages it and frequently ruins it, to the opposite that it never damages, and frequently improves it; also that when frozen cement is found to be damaged, the injury has been due to some of the inscrutable influences which so mysteriously effect it. To 
freeze cement may increase its strength if all of the conditions are favorable for frozen cement; but to freeze it when these conditions are not favorable may render it friable and worthless. It is not known just what these conditions are which are favorable to frozen cement, and as yet they seem to have defied detection. It can then be readily understood how one experimenter may accidently comply with a considerable number of the favorable conditions referred to, and obtain results which show that the freezing had added perhaps as much as IOO per cent. or even 200 per cent. of the strength of the unfrozen cement. And other experimenters may have complied with a less number of these unknown conditions and obtained but moderate strength, while a third may not have complied with any and his results show that his cement has no strength at all in consequence of having been frozen. Each tester, having confidence in the results of his own operations, has corresponding convictions; and again the engineering periodicals have recorded the results of many pieces of work in practice which were built in freezing weather and which show no evidences of damage, as well as many failures which seem to be attributable wholly to the effects of low temperature.

But the literature is fast being enriched with the result of experience and experiments, and there is just ground for hope that at no very distant day we may have such knowledge as will permit us to say, with some degree of certainty, what the result will be if cement is placed in work and frozen under certain specific conditions.

It is the aim of the writer to give in the first part of this article an abstract of manyof the experiments and observations that have been made upon this subject, the material having been taken from the volumes of the standard engineering works and periodicals as found in the Engineering Library of the University of Iowa. In the second part of the article will be given the results of freezing tests performed by the writer upon blocks of natural cement mortar and upon portland cement concrete. At the end of the article will be given a bibliography of literature relating to the behavior and use of cement when subjected to freezing. Frequent foot notes have been used for the convenience of those wishing to read the original articles. to which reference has been made in the text. 
ABSTRACTS AND REVIEWS OF EXPERIMENTS.

Perhaps the most extensive and practical series of tests on mortars were made under the direction of the Cement Committee of the Austrian Society of Engineers during the winters of 90-9I and 9I-92. ${ }^{I} \quad$ These experiments were made upon full sized walls of brick, and of limestone rubble. The brick walls were 3.28 feet long, 6.56 feet high, and I 2 inches thick; the rubble walls were 3.28 feet long, 6.56 feet high, and 16 inches thick. Various mortars were used of lime, portland cement, roman cement, and a mixture of portland cement and slag cement. Cold and hot, and fresh and salt waters were used in the mixings. The walls were built in December, the temperature varying from 6 to 26 degrees Fahrenheit and were torn down in the following June.

The conclusions of the Committee from the experiments were:

"That in brick masonry laid in freezing weather, mortar into which any part of lime enters should not be used. Roman cement behaved fairly well under such conditions, and portland mortars gave good results. * * * * * That the use of warm water gave somewhat better results than cold, and that salt materially increased the resistance to frost. With rubble masonry using either sandstone or limestone, lime mortar was entirely out of place, and roman cement mortar gave poor results unless mixed with salt. Portland cement mortar behaved well especially with the use of salt." The final recommendation of the committee was, "that in laying brick or rubble masonry in winter, only portland cement mortar should be used, mixed with salt, if possible."

This is the only instance which the writer could find on record where experimental walls were built in order to study the effects of freezing upon the mortar and is believed to be the only way in which the most reliable results can be secured.

Among the most extensive series of tests on the freezing of mortars are those made by Percy L. Barker and Allan Symonds of the Thayer School of Engineering, Dartmouth College. ${ }^{2}$

Eng. Rec. Vol. XXIX, p. 351.

2 Eng. News, Vol. XXXIII, p. 282. Abstract, Michigan Engineers Annual for 1896. 
The test pieces were made in the form of prisms $I^{\prime \prime}$ in cross section and $6^{\prime \prime}$ long, and were broken as beams. There were 3500 test specimens made, I9I I in fresh water and the remainder in salt water. The mortar was mixed I to 3 and $I$ to 2 , and the prisms were allowed to set before being exposed, a fact worthy of particular note. They were broken at intervals of from 2 to 60 days. As a result of their investigations they propose the following set of specifications for cement work in cold weather:

"The surface shall be free from ice.

"If portland cement is used salt shall be used in the mixing water in the proportion of one part salt to 15 parts water by weight.

"The mixing shall be done at a temperature not exceeding 50 degrees $F$. and not below 35 degrees F.

"All joints shall be pointed with a portland cement mortar or a mixed mortar of portland and natural cement.

"In no case shall Rosendale mortar be used where ice can form in contact with it.

"Use portland cement in preference to natural cement."

These experiments show the beneficial effect of salt in mortar that is subjected to freezing. The tests seem to prove that provided the cement can be protected until it has had time to set, it will be safe to lay masonry in freezing weather. It will be noted that a maximum temperature of 50 degrees Fahrenheit is prescribed.

Some very interesting and practical series of experiments were made by Arthur G. Fogg, of Roslindale, Mass. ${ }^{\mathrm{I}}$ The tests were conducted during the winters of ' 95 and ' 96 upon both portland and natural cement mortars, each mixed I to I. The following are the conclusions deduced from the results of the series, an entirely different set of briquettes being made for each sets of tests:

"Series I. Portland cement mortar gains strength when exposed to freezing temperatures whether before or after setting.

"Series 2. Portland cement is not destroyed by alternate freezing and thawing but sets slower.

"Series 3. Freezing retards the setting of portland cement

I Eng. Rec., Vol. XXXIX, p. 93. 
mortar, but long time tests should be made to see if the frozen ultimately becomes as strong as the unfrozen.

"Series 4. It is not safe to allow a slow setting cement to freeze in water in less than four days, but a quick setting cement may freeze in 12 hours without injury, provided it remains frozen until set.

"Series 5. Portland cement mortar is injured more if it alternately thaws and freezes under water before it has had time to set hard.

"Series 6. Rosendale cement mortar is not injured by freezing in air, but strengthened. (Mortar was kept frozen for a number of days before being thawed out.)

"Series 7. When Rosendale mortar is mixed stiff it is not safe to let it freeze in water in less than six weeks, and as mixed in practice it is not safe in less than two months."

The conclusion reached in series 6 by Mr. Fogg has been reached by a number of other experimenters. Uriah Cummings, in his "American Cements," p. I95, has the following: "The many experiments that have been made by different authorities in the freezing of green cement samples would seem to indicate that portland cement mortar will sustain severe freezing without appreciable disturbance of the exposed surfaces, but it suffers in loss of strength in some cases as much as 50 per cent. While the rock cement mortars will show a disintegration to the depth of $1 / 4$ to $1 / 2$ inch on the exposed surfaces, yet the portions not disintegrated are shown to have sustained no loss in strength, and in some instances the strength is above the normal. A series of tests made by the author, the results of which are herewith tabulated, differ somewhat from those of other writers, resulting, no doubt, from having experimented with different brands of cement. All of the briquettes were given one day in air and six days in water, those in the second column being placed in water and set outside, where they were soon frozen, and so remained in solid ice until thawed out and broken at the end of the seventh day. All of the briquettes represented in the second column, after being thawed out, were shown to have lost equally in area, by scale and disintegration, to a depth of $1 / 8$ inch on all sides. There was no appreciable differences in the losses, the portlands having suffered equally 
in that respect with the rock cements. All of the briquettes were guaged neat by the same person, and were treated alike as to placticity and temperature. There is a surprising gain in strength of the rock cements by freezing. With the portlands, the slow and medium setting samples held their own, while the higher testing portland under ordinary rules lost 50 per cent. of equal areas by freezing."

Table of tests of the relative strength of frozen and unfrozen samples of the same cement.

\begin{tabular}{|c|c|c|c|c|c|}
\hline Kinds of Cement & 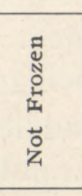 & 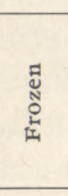 & 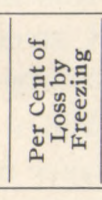 & 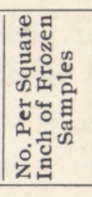 & 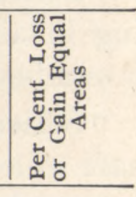 \\
\hline Medium Burned Rock Cement & 138 & I 35 & 2.17 & I94 & Gain 40 \\
\hline Hard Burned Rock Cement & 226 & 225 & 0.44 & 323 & Gain 43 \\
\hline Slow Setting Portland & 388 & 280 & 27.83 & 402 & Gain 04 \\
\hline Medium Setting Portland & 419 & 292 & 30.31 & 419 & Gain 00 \\
\hline Quick Setting Portland & 433 & 255 & $4 \mathrm{I} .4 \mathrm{I}$ & 366 & Loss I 5 \\
\hline
\end{tabular}

Another set of experiments which points out the fact that natural cements may be greatly strengthened when frozen under certain conditions was made by A. C. Hobart, of the University of Illinois. His results are published in the Technograph of the University of Illinois for ' 97 and '98. "A room was available which could be kept at a constant temperature of 20 degrees Fahrenheit. The briquettes were first allowed to set for different periods I, 2, 3, 6, I2, 24, 72, I68 and 336 hours before being frozen, being kept at a temperature of 54 to 60 degrees Fahrenheit. The experiments were made with natural and portland cement both neat and with sand. The briquettes were allowed to freeze for six days and were then thawed for 18 hours before breaking, by being placed in hot water.

"By the above treatment the hardening of the portland cement seemed to be simply retarded. After thawing they went on gaining in strength. The natural cements, however, were 
improved by the freezing. By examining the diagrams in figures I and 2 the results of freezing Utica and Louisville Star cements can be seen graphically. The maximum strength obtained with the above treatment seems always to occur with a less initial set than 24 hours. Freezing under the above conditions seems to affect the cements mixed with sand more favorably than the neat cements."

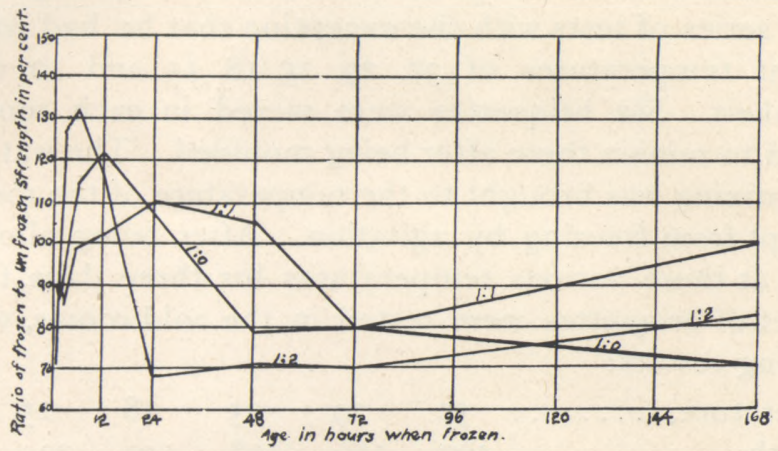

FIGURE 1

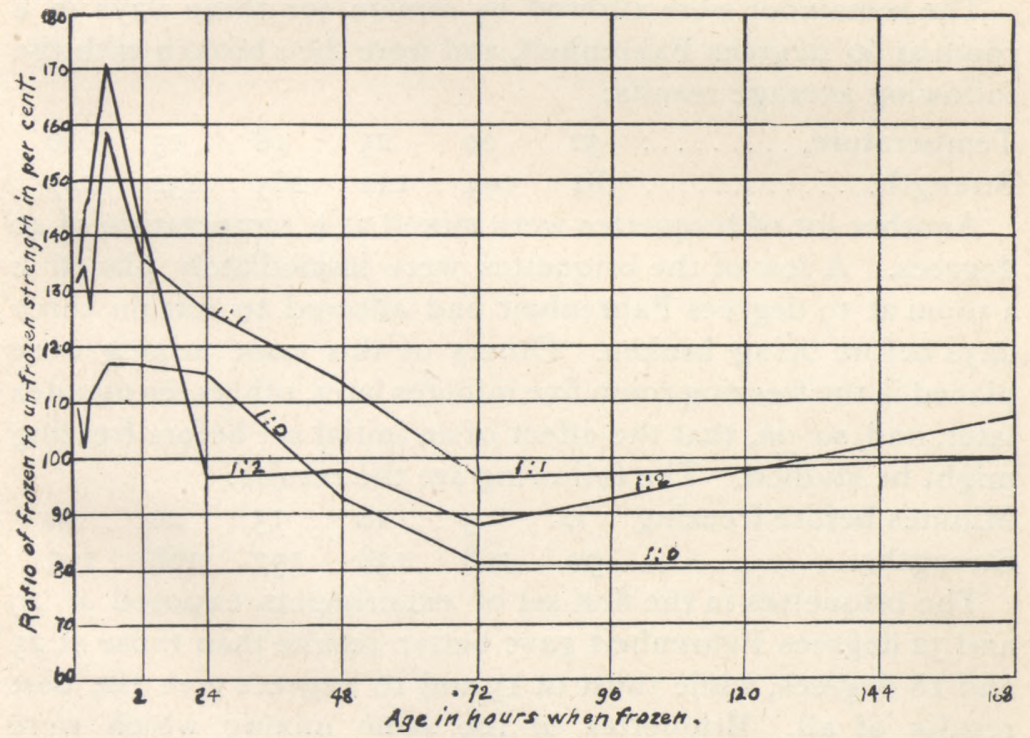

Figure 2

EFFECT OF FREEZING NATURAL CEMENT MORTARS AFTER HAVING SET VARYING LENGTHS OF TIME (FROM HOBART'S ARTICLE IN TECHNOGRAPH FOR 1898). 
The minimum quantity of water used in preparing the above specimens and after the setting process had advanced as far as was the case with most of the briquettes there was little or no water left to disrupt by forming ice, and the hardening process seems then to have gone on better under the above conditions of freezing than at a higher temperature.

Mr. Charles A. Godfrey, of Manchester, England, ${ }^{\mathrm{T}}$ made a similar series of tests. with the exception that he had rooms at constant temperatures of $32,29,25,18,15$ and 10 degrees Fahrenheit. Six briquettes were mixed in each room and allowed to remain there after being moulded. The water used in the mixing was brought to the temperature of the room and was kept from freezing by agitation. After being allowed to remain at these various temperatures for three days, three of each set of briquettes were tested in the cold rooms, with the following results:

Temperature, ........... 32

Strength,......... I 90

$\begin{array}{rrrrr}29 & 25 & 18 & 15 & 10 \\ 189 & 108 & 140 & 203 & 280\end{array}$

The remainder were allowed to remain for three days in a room at 60 degrees Fahrenheit, and were then broken with the following average results:

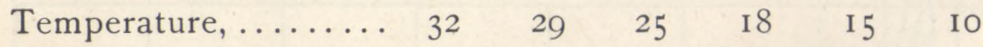

$\begin{array}{lllllll}\text { Strength............ } & 382 & 194 & 142 & 263 & 232 & 147\end{array}$

Another lot of briquettes were mixed at a temperature of 40 degrees. A few of the briquettes were immediately placed in a room at 19 degrees Fahrenheit and allowed to remain three days before being broken. Others of this same mixing were placed in the freezing room five minutes later, others ten minutes later, and so on, that the effect of an initial set before freezing might be studied. The following are the results:

$\begin{array}{lllllll}\text { Minutes before freezing } & 0 & 5 & 10 & \text { I } 5 & 20 & 30\end{array}$

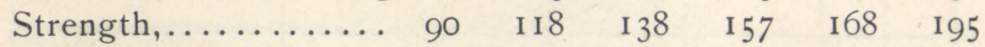

The briquettes in the first set of experiments exposed at 29 and 32 degrees Fahrenheit gave better results than those at 25 and 18 degrees, while those at 15 and 10 degrees give the best results of all. Briquettes of the same mixing which were afterwards allowed to remain in a room at 60 degrees Fahren-

I Eng. Rec., Vol. XXXIX, p. 75. 
heit show different relative results. Those that were first exposed at 32 degrees were strongest. All of them show a healthy gain in strength with the exception of those exposed for the first three days at a temperature of 10 degrees Fahrenheit, which shows a loss. There is evidence in the above figures of a very considerable range and personal equation. Why would not cement exposed as above go on increasing in strength indefinitely, and ultimately become practicaly as strong as cement that had not been exposed to these trying conditions? Mr. Godfrey sums up the results of his experiments in the following: "Frost has a deleterious effect on portland cement and though cement may, shortly after being frozen, appear to be seriously damaged it will improve with time, but it is not probable that it will ever regain its original strength." Mr. Godfrey's last set of experiments above noted show conclusively that the greater the set attained before being frozen the less will be the injury done by freezing. The strength does not only increase with the amount of set but it is also a fact that cement mortars set much slower at low temperatures, which facts should be kept in mind when the time of setting is an element in placing cement work. Figure 3, taken from Johnson's Materials of Construction, shows the effect of temperature on the setting of portland cement. "By examina-
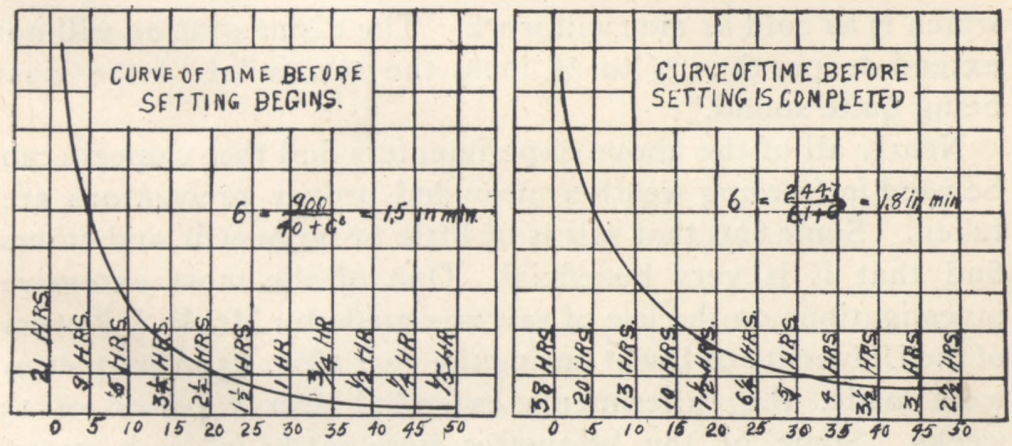

Figure 3.

SHOWING EFFECT OF TEMPERATURE ON THE SETTING OF PORTLAND, CEMENT MORTAR, 1C: $3 \mathrm{~S}$; THE TEMPERATURE IS GIVEN IN DEGREES CENTIGRADE. (FROM JOHNSON'S MATERIALS OF CONSTRUCTION. ) 
tion of the figure it will be seen that a mortar that will set completely, by the method of testing employed, at 35 degrees Centigrade (95 Fahrenheit) will require 4 hours, and at 0 degrees Centigrade ( 32 Fahrenheit) will require 38 hours."

Mr. Cecil B. Smith, Men. Can. Soc. Eng., ${ }^{\mathrm{I}}$ made two sets of briquettes. The first he exposed immediately after mixing, and the other was first allowed to set. His portland cement tests show that briquettes exposed immediately after moulding were weaker than those which were first allowed to set. Natural cement he found could not be used if exposed before setting, but if first allowed to set they gave better results. A 2 per cent brine solution strengthened the briquettes. In another series of salt water tests the sand and water was cold, the water being so cold that it formed a sort of a slush. The specimens were mixed in the laboratory in about six minutes and were then exposed. The briquettes thus exposed with salt water showed very little injury and seemed affected chiefly at the surface. He further says:

"The general results of the experiments to the writer's mind point to the idea that in any weather not extremely cold, say not lower than $I_{5}$ degrees Fahrenheit, masonry work can be laid with cold sand, cold cement and cold water, provided the natural time of the set of the cement is not more than five or six hours. The same work may be done down as low as zero, which is as cold as men will work. The disintegration will not extend deeper than $1 / 4$ to $1 / 2$ inch, the remainder of the mass being quite sound."

Nearly all of the above experimenters find that cements can be used in freezing weather, provided proper precautions are taken. Some find that salt is of little or no benefit, and others find that it is very beneficial. One of the most extensive investigations on the use of salt was made by Mr. M. I. Powers of the University of Iowa ${ }^{2}$ during the year I 899 . 3,500 bri quettes were made, the experiments extended over a period of I3 weeks. Some of the briquettes were made in fresh water, some in a 3 per cent solution, and some in a Io per cent solution

I Jour. W. Soc. Eng., Vol. I, p. 681.

2 Transit Vol. 1, No. 2, University of Iowa. Abstract, Eng. News, Vo1. IXXVI, p. 481. 
of salt. Salt water seemed to increase the strength of the natural cement at first, but at the end of 13 weeks the briquettes mixed with salt water seemed to be decreasing in strength. A Io per cent salt solution gave stronger briquettes at first with a natural cement than with a 3 per cent solution, while in portlands they gave weaker briquettes. In an extended series of tests at Governor's Island, N. Y., under the direction of Col. D. C. Houston, U. S. Eng., ${ }^{\mathrm{I}}$ it was found that briquettes mixed in sea water and afterwards immersed in sea water until broken were stronger than corresponding briquettes similarily treated with fresh water. 253I briquettes were made and the tests were in progress from May, I889, until July, I890. It was found that salt water gave natural cements a permanent gain of 20 per cent and portlands a permanent gain of Io per cent. The above experiments at least prove that salt is not so injurious to cement as to render its use dangerous. Records show that under many conditions it increases the strength of mortars in which it is used. It is, however, not desirable to use it in walls of buildings, in which appearance is an object, as a white efflorescence will appear on the surface of the masonry.

In regard to the proper proportions of salt to be used for cements under different freezing temperatures, Figure 4, taken from Johnson's Materials of Construction, shows the effects of different proportions of salt at various temperatures. "In the upper half of the figure is shown the effect of salt on tension briquettes of portland cement, which were moulded in a room where the temperature was 8 degrees Fahrenheit, and where the briquettes were frozen hard in half an hour and remained frozen 60 days. They remained in the open air and hardened when they thawed out. It should be noted that the briquettes grew weaker between the ages of $61 / 2$ and $91 / 2$ months. In the lower half of the figure are given the results of tests of the same cement mortar moulded in air at a temperature of $2 \mathbf{I}$ degrees Fahrenheit, and left frozen for 3 days and then placed under water for the remaining period. In the former period (hardened in air) we might conclude that more than 5 or 10 per cent weakened the mortar somewhat, while in the latter

I Eng. News, Vol. XXIV. p. 542. 
(hardened in water) the briquettes increased in strength up to 20 per cent salt."

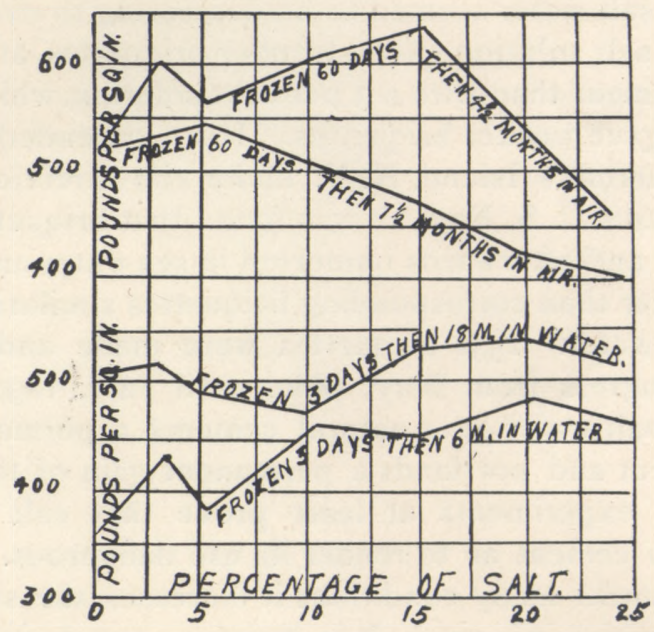

FIGURE 4.

EFFECT OF SALT ON PORTLAND CEMENT MORTAR, 1C,: 2S, MADE IN FREEZING WEATHER. (FROM JOHNSON'S MATERIALS OF CONSTRUCTION.)

Soda has been used, principally in Europe, ${ }^{\mathrm{I}}$ in mortars that were to be laid in freezing weather. A solution of soda is taken of about 2 pounds to a gallon of water. This is then mixed with an equal quantity of water as it is used. The effect of the soda is to hurry the setting of the cement especially at the surface, the interior however remains humid for some time. Its use is also objectionable in masonry of the walls of buildings, on account of the discoloration produced.

$\mathrm{Mr}$. Bernhofer, an Austrian engineer, ${ }^{2}$ performed an interesting experiment on the effect of adding crystallized soda to portland cement and then exposing it to freezing. "The mortar consisted of cement I part, lime I part, and river sand 3 parts, and was mixed with I kilogram of soda dissolved in 2 litres of water. The experiment commenced at 7:30 P. M. on Dec. 9th, I890, and lasted until IO A. M., Dec. Ioth, a period

I Eng. Rec. Vol. XXVIII. p. 348, Eng. News, Vo1. XXIX. p. 140.

2 Eng. News, Vol. XXIV. p. 316. 
of $14 \frac{1}{2}$ hours. During the night the temperature fell to $-31 \frac{1}{2}$ degrees Centigrade and was still i 5 degrees Centigrade at the close of the experiment. The specimens were then baked in a hot oven for 3 hours. It was found that the cement was not harmed."

Alcohol and glycerine have been used in the gauging of mortars exposed to freezing. Fig. 5, taken from Johnson's Materials of Construction, shows the proper percentages of salt, glycerine and alcohol required in the mixing water to prevent cement from freezing at the various temperatures from 32 degrees to o degrees Fahrenheit. From these resuits it appears that salt is the cheapest as well as the most efficient agent. From this diagram we see that, approximately, the number of degrees Fahrenheit the temperature is lower than freezing, equals the per cent of salt to be used.

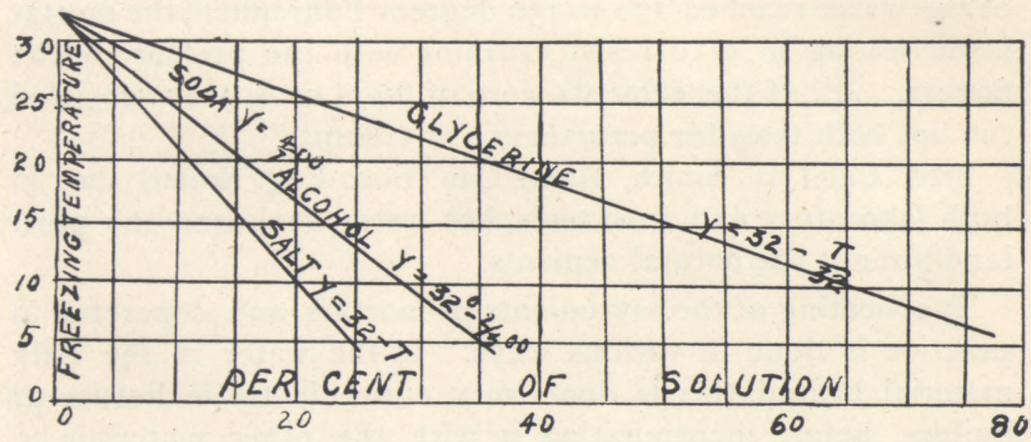

FIgURE 5.

EFFECT ON THE FREEZING POINT OF CEMENT OF VARIOUS PROPORTIONS OF GLYCERINE, ALCOHOL AND SALT. (FROM JOHNSON'S MATERIALS OF CONSTRUCTION.)

Heating the water or other ingredients of mortars has often been done in cold weather, but the results of this practice have been as discordant as the results of mortars treated by methods already noted.

Mr. Wm. W. Maclay ${ }^{\mathrm{I}}$ made a series of very valuable experiments by this method. Two sets of briquettes were made; in one the ingredients were heated to a temperature of 40 de282.

I Trans. Am. Soc. C. E. Vol. VI. Abst. Eng. News, Vol. XXXIII. p. 
grees Fahrenheit and in the other to Ioo degrees Fahrenheit. The hotter mixture was but 7 to 29 per cent as strong as the colder mixture. In I to 2 mortars it was but 30 per cent as strong. This is what one would naturally expect as it is well known that moderate temperatures are more favorable to the setting and hardening of cement than the extremely high temperatures of sumner, which increase the activities of cements and causes the partial expenditure of its energies before it can be put in place, as well as conduces to unsoundness.

Prof. Fred. P. Spaulding, ${ }^{I}$ M. Am. Soc. C. E., of Cornell University, has probably made the most extensive experiments with the use of hot water upon mortars, made from a great many brands of cement. "Four were slightly affected by the use of hot water, the remainder were materially weakened, and three were rendered entirely worthless when the temperature of the water reached I 20 to I 50 degrees Fahrenheit, the mortar never setting so as to resist crushing with the pressure of the fingers. All of the cements were of good quality and resisted the hot bath tests for permanence of volume."

Prof. Cecil B. Smith, Mem. Can. Soc. Eng. found that in both laboratory and frost tests, hot water weakened the portland but not the natural cements.

The heating of the ingredients of mortars and concretes in practice is done in various ways. If the water is the only material heated, this is done very conveniently in kettles or boilers, before incorporating it with the other materials to be used. To the writer's mind this is not the best way to proceed if the stone or sand is frozen and not perfectly dry. The activity and energies of the cement is aroused by the hot water, and if the mortar is then placed in contact with the frozen stone or gravel this activity is suddenly checked before the cement can bond with the stone. In such a case it would be much better to heat the stone, brick or sand, as the case may be, sufficiently to remove the frost. Brick and rubble stone may be heated by piling around a fire, and broken stone or gravel may be heated by piling around pipes or improvised flues, through which steam or hot air is passing. It is not best,

I Journal W. S. C. E. Vo1. 1, p. 681. 
in the writer's opinion, to remove frost by immersing the materials in hot water, as so much water is absorbed, and held by capillary action, that the mortar will almost always be too wet, and if exposed to a very low temperature the water in the mortar on freezing will expand and destroy the bond between the mortar and stone or brick. If the green masonry or concrete can be protected from freezing for sufficient time, removing the frost from materials by this method, can be done advantageously, but is not as safe as heating by other methods under ordinary conditions.

Wm. H. Ward, ${ }^{\mathrm{I}}$ a contractor, heated broken stone by immesring it in hot water. A large water tight tank was filled. This was kept heated by passing steam through it. The buckets of broken stone were lowered into the water and allowed to remain until thoroughly heated. The stone was then run through the mixer and immediately put in place, and protected by tarpaulins, etc. Heat was retained a sufficient length of time to allow the cement to set. If the concrete in this case had been used in exposed walls where it could not be protected by tarpaulins, etc., it may be doubted whether the result would have been so satisfactory as reported. The activity of the cement would have been greatly accelerated by the highly heated materials and the greater quantity of heat retained by the additional water, and then the sudden and decisive check to the chemical action, and the expansion of the surplus water on turning to ice in the mortar, would have resulted disastriously. This surplus water over and above that required in the mortar to complete the chemical activity of the cement is, in the writer's opinion, the chief cause of damage.

The writer had occasion to put in a concrete base for an engine during the cold weather of December, I899. It had rained just before the freezing, and the gravel pile was full of ice. This was heated very expeditiously with the following improvised apparatus. A piece of well casing $1 \mathrm{I}^{\prime \prime}$ in diameter and about $10^{\prime}$ long happened to be at hand. This was placed with one end on the ground and the other slightly raised to create a draught. A sort of a fire place was built in front of

I Eng. News, Vol. XXXIII, p. 181. 
the lower end and on building a fire here the casing became quite hot along its whole length. The gravel was piled around the casing and soon became thawed out. Salt was used with warm water for mixing the mortar, as the sand was frozen. To all appearances the concrete hardened perfectly. The object in thus treating the materials was simply to extract the frost and ice from them. This being done, the nature and location of the work was such that the green masonry could be easily kept from freezing by simply covering with sacks.

Thus from experiments one might draw abundant proof in substantiation of either of the statements, Ist, that cement when exposed to freezing is rendered worthless; $2 \mathrm{nd}$, that it is to all practical purposes unaffected and as sound, strong and reliable as though unfrozen; or 3 rd, that freezing increases its soundness and strength very appreciably. These various and seemingly altogether discordant results are due, as already pointed out, to local conditions under which the experiments are carried on and to the methods of testing employed by the experimenters.

Effect of Freezing on Cement Mortars and Concretes as Shown by a Study of Reports of Masonky Laid in Freezing Weather.

In this as in all other subjects, experience, as distinguished from theoretical deductions, or eve.ı experiments in the laboratory, is the best teacher. It is to be very greatly regretted that more of those who have been compelled to use cement mortar and concrete in freezing weather have not made public their results, and that the accounts of those who have publishd their results were not given in far greater detail, especially concerning the conditions under which the work was done other than that of temperature alone. It is, in the writer's opinion, on these other conditions, and combinations of them, that the success of the work depends. There can be no doubt from the above and what is to follow that cement may be increased in strength and soundness by freezing; or the opposite conclusion may also be reached, that it may be damaged or ruined by freezing. It must be evident, therefore, that freezing in itself does not damage cement, but that freezing in combination with certain other undefined conditions, the in- 
fluences of which we do not know, can cause its absolute ruin. From the following extracts, taken from the reports of practice, this absence of minute detail is very noticeable; but since field practice and methods are far more uniform than are those of the laboratory, the lessons taught by them are most valuable.

"In the construction of the Sibley bridge, at Sibley, Mo.," a warm brine was used consisting of an 8 per cent salt solution and the best Louisville cement in making the mortar. The masonry was laid in weather as cold as 25 degrees below zero, and finished the last part of December, I889. Subsequent examination has shown the mortar to be as good as that laid in warmer weather."

Mr. Alfred Noble, M. Am. Soc. C. E., ${ }^{2}$ records some interesting pieces of work. "In the construction of the St. Mary's Falls Canal in October, 1877 , when work was discontinued, due to the approach of winter, adjacent portions of the wall were laid in I to I portland and I to I natural cement mortar. Both were laid during a light rain on the last day of the work. The next spring the natural cement mortar was disintegrated to a depth of 3 to 4 inches, while the portland cement mortar was sound. In constructing a concrete dam in the same locality in February, when the temperature averaged zero degrees, salt was used in the mortar and the result was satisfactory."

"In filling the cassions for a bridge across Clark's Fork on the Columbia River in Northwestern Montana, ${ }^{3}$ the mortar used in the concrete consisted of I to 3 portland. The piers were built in very cold weather and there was no apparent defect in the masonry."

"Four small piers of the St. Louis River bridge on the Northern Pacific R. R., near Duluth, 4 were laid in weather averaging o to 20 degrees Fahrenheit. Portland cement mortar I to $I / 2$ for facing, and I to $2 \frac{I}{2}$ for backing was used. During extremely cold weather salt was used freely and the sand warmed (not made hot). The mortar laid in the coldest weather seemed as strong and durable as that laid in warm weather."

\footnotetext{
I Trans. Am. Soc. Eng., Vol. XXI, p. 114.

2 Trans. Am. Soc. C. E., Vol. XVI, p. 79.

3 Trans. Am. Soc. Eng. Vol. XXI, p. 114.

4 Ibid.
} 
"In the walls of the East River Bridge ${ }^{\mathrm{I}}$ it was found that the Rosendale mortar used in the masonry walls in freezing weather was disintegrated to a depth of several inches and needed repointing. Otherwise the mortar was all right.

"Mr. Shanahan, Superintendent of Public Works, New York, stated to Mr. T. C. Clarke, M. Am. Soc. C. E. ${ }^{\mathrm{r}}$ that in his experience with masonry on the Erie Canal, that he would as willingly build masonry in the Winter as in the Summer as far as durability was concerned. Rosendale mortar (tolerably strong) was used and was mixed with the strongest brine water, saturated with salt so that it would foam on top. He said he never knew a case to fail in that way. Mr. Bogart, in referring to the above piece of masonry, which was a retaining wall of the West Shore Railway that runs along the canal, said th= masonry laid in cold weather without the proper use of salt failed, while the other masonry was in good condition."

"Rosendale mortar was used around the wasteway of the reservoir at Hanover, Mass. ${ }^{2}$ This was laid in the Winter time and water stood over the masonry more or less. ln the spring the natural cement mortar was a mass of scales. The same brand of cement built at the same time in the walls was disintegrated to a depth of about $1 / 4$ of an inch and was in good condition underneath."

Mr. J. R. Cross, in the Trans. Am. Soc. C. E., ${ }^{\mathrm{I}}$ states that in mortar laid in the construction of a masonry dam in the Winter on the Croton River, where salt was used, satisfactory results were obtained."

Mr. Albert J. Herries, in relation to his work on the Lake canals says: "When the construction has been under the care of competent engineers we have never had any difficulty or bad results from cements used in freezing weather. The stone is thoroughly cleaned of snow and ice and a saturated solution of salt is used. Natural cement is used in the work." Mr. A. P. Amann, an Australian engineer, is quoted in the same article as saying that some of his most important works were carried on during hard Winters with trained men and proper precautions.

I Trans. Am. Soc. Eng., Vol. XXI, p. 114.

2 Michigan's Engineers' Annual for 1896. 
Mr. Rogers, in the Eng. Rec. of Aug. 26, I899, thus describes the construction of a base for a Ioo-ton shear leg crane built during freezing weather. "The proportion used was I part Milwaukee cement, 2 parts sand and from 4 to 5 parts broken stone. About half the mass was below water. Ice formed over the top of the concrete every night, sometimes to a thickness of six inches, until the work was above the surface of the river. When the work was above water level of the river no attempt was made to protect it from frost. The materials and water used, however, were heated with reasonable care and about a double handfull of salt was added to each bucket of water. Several months later it was necessary to cut through the masonry and it was found to be thoroughly set."

It would appear that if cement could be depended upon when used under as severe conditions as some of the above that there are but few cases where it cannot be used for work in the winter time. In all probability the sides of the above base showed the effects of surface disintegration where it had been frozen in contact with water, but on account of the size of the mass this effect would be of small consequence.

Mr. F. von Empberger, a German Engineer says:I "The German practice is not to work below 28 degrees Fahrenheit, mainly because men will not work when it is colder.(?) Cold weather is always preferable for concrete work because it is generally damp, and I consider that heat and drouth are more dangerous for fresh concrete than cold weather, because dry concrete is absolutely valueless."

Mr. A. E. Cary in a paper before the Institute of Civil Engineers of Great Britain ${ }^{2}$ says, that with cement gauged as in making briquettes, frost produces no deleterious effects, the setting properties being rendered dormant thereby, and long time tests being practically identical with those maintained at higher temperatures. In public works, in which an excess of water is generally used, the effect of frost is to disintegrate the concrete by the expansion of the water in freezing. Where cement mortar is used in very cold or freezing weather the

\footnotetext{
I Michigan Engineer's Annual for 1896.

2 Eng. Rec. Vol. XXXVII. p. 98.
} 
exposed points ought to be raked out and pointed when the season is more favorable.

In a letter to E. W. Muenscher, C. E., Wm. T. Brain, a brick and stone mason and contractor, ${ }^{\mathrm{I}}$ says: "Care should be taken to select dry brick so the moisture will be absorbed from the mortar as quickly as possible, and then the frost will not swell and burst the joints, and destroy the beauty and strength of the wall; which would be the case if the brick were wet and frosty. The frost would form ice in the joints of mortar and swell and destroy them. I have found in all cases where such care has been taken that walls laid in the very coldest weather are stronger than they would be if laid in the heat of summer, for the reason that the mortar dried slower, and adherred firmer to the brick."

W. D. Lovell, C. E., contributes the following from his field notes in reference to this subject. "It became necessary to put in the foundations for a water tower at Armstrong, Iowa, during the very coldest weather of the year I895. The foundations consisted of concrete footings and rubble work. In placing the concrete it became frozen solid as soon as laid and remained in this condition until spring. On thawing out the concrete was still soft, but as soon as the frost was out the cement set and hardened in all respects as well as if it had been placed in warm weather. The water tower is now standing on these foundations, and they have shown no sign of weakness in any way."

At Des Moines, Iowa, ${ }^{2}$ in November of the year 1896 , a brick pavement was laid on a concrete foundation. One year later when samples were taken up it was found that the concrete was still soft. These samples hardened after being placed in water for Io days. Prof. Higgins, C. E., held that "the cement would go on setting for years, covered as it was shortly after being put in place with practically an air tight covering, but the weak cement would be damaged by the jarring of vehicles."

When this work was put in it is said the weather was so cold that the concrete "balled" on the workmen's shovels. About I 8 months after being laid, a sample of this concrete was deliv-

I Michigan Engineer's Annual for 1896.

2 Eng. Rec., Vol. XXXVII, p. 98. 
ered to Prof. A. V. Sims, about 6 hours after being removed, who reported on its behavior as follows: "When this concrete was delivered it was soft and friable and had to be handled with care to prevent breaking. The volume of the sample was. about equivalent to a 6 inch cube. Part of it was immediately put in water where it hardened gradually, finally attaining considerable strength; the remainder was kept in air and did not strengthen at all."

Prof. de Schmedt, of Washington, D. C., relates a somewhat similar experience during the winters of ' 84 and ' 85 . Concrete in pavement laid in the Fall was still soft the next Spring, but in the following Fall, when there was occasion to cut through the pavement, the concrete was found to be as hard as rock itself. These two are the only cases of which record could be found where the action of cement was so retarded-presumably by freezing.

G. S. Greene, Dept. of Docks, N. Y. City, ${ }^{\mathrm{I}}$ says, with reference to masonry work in freezing weather: "Instructions in making concrete in cold weather are, where it is not to be disturbed after being put in position, that it may be made as longas the materials do not freeze to the tools, or as long as the mortar does not freeze so that it cannot be worked with a trowel, or in the case of concrete, cannot be rammed."

Prof. Ira O. Baker in his work on Masonry Construction says upon this subject: "Mortar composed of one part portland cement and three parts sand is entirely uninjured by freezing and thawing. Mortar made of cements of the Rosendale type, in any proportions, is entirely ruined by freezing and thawing. It is probable that this difference is due to the fact that the expansive force of the water in freezing is less than the strength of the richer portland cement mortars and greater than any Rosendale cement mortar. In the latter case freezing is equivalent to agitating the mortar after it is partially set. The use of salt, and more especially of sea water, in mortar is objectionable, since the accompanying salts usually produce efflorescence. It is not certain that the addition of salt to portland cement mortar does either any good or any harm, it appears to slightly retard the first setting. When masonry is to be laid in

I Michigan Engineer's Annual for 1896. 
freezing weather, frequently the mortar is mixed with the minimum amount of water and then thinned to the proper consistency by adding hot water just before using. This is undesirable practice. When the very best results are sought, the brick or stone should be warmed-enough to thaw off any ice upon the surface is sufficient-before being laid."

Prof. Johnson in his work says: "The worst set of conditions for cement mortar to stand is that of a succession of temperatures below and above the freezing point. If the mortar freezes as soon as laid there is no bond to be broken, and no injury can result provided that when it thaws out it remains unfrozen long enough to harden. But if it begins to set and then freezes again before the cohesive strength of the cement can resist the expansive effect of the frost, then it is cracked and these severed surfaces will never again unite. Water then enters such cracks and further disintegration follows."

Prof. F. P. Spaulding on page 238 of his work on Cements has the following: "Mortar of good portland, or of many kinds of natural cement, is not injured by freezing when frozen before it is set. Cement scts with extreme slowness, if at all, while frozen, but after thawing sets and hardens properly. Mortar frozen tor short periods-a few days-does not set while frozen, but the experiments of Prof. C. B. Smith at Magill University seem to show that if kept frozen for a sufficient period it may finally set while frozen. The hardening of cement which has been frozen is much slower than that unfrozen, but it may ultimately gain the same strength.

"The injury done to mortars by low temperatures is probably not due to freezing, but to alternate thawing and freezing while the work is still fresh, before hardening is sufficiently advanced to render the mortar capable of adequately resisting the expansive forces. The effect of frost upon mortar which has set is similar to that upon stone or brick, and is due to the increase of volume of the water freezing in the pores. Its effect therefore depends upon both the porosity of the mortar and upon the strength it possesses to resist disruption. The more rapid acquisition of strength by portland cements may give them the advantage they possess in this regard.

"Prof. Le Chatelier, from his experiments upon the matter, 
concludes as follows: "This disintegration like that of broken stone is more easily accomplished when the mortar offers small mechanical resistance, when the total volume of voids is large, and the dimensions of each separate void is small. When the voids are sufficiently large, the ice breaks with a pressure less than that which will rupture the mortar. For this reason mortars of large sand are less affected, the voids being large and less numerous.'”

But since from some of the experiments which have been tried it has been shown that if water cannot expand its ten per cent or thereabouts it will not crystalize, it is hard to reconcile some of these theories to this condition.

\section{The Author's Tests.}

The experiments hereinafter described were made by the auther at the University of Iowa during the Winter and Spring terms of the year 1899 on blocks of natural cement mortar, and portland cement concrete, which were crushed in the 100,000 pound Riehle testing machine of the Engineering Department. Valuable assistance was rendered by Mr. Keerl, a student in the department, in preparing the specimens; also by Messrs. White, Barber and Miller, of the class of '99, in crushing the specimens broken at 80 days. The author desires particularly to acknowledge the assistance rendered by Prof. A. V. Sims through his interest and valuable suggestions in carrying out the experiments and working up the results. Messrs. Robish, Beard, Meggars and Hunter, at that time Juniors in Civil Engineering, made the tests on briquettes, the results of which are incorporated in this article.

The cement used in the experiments was taken from the stock of the contractor who was at this time putting in the foundations and basement wall of the new Collegiate building. Prof. Sims has kindly permitted the results of his observations on the behavior of the same cement used in the masonry work to be incorporated in this article.

The blocks were cylindrical in form, being one and a half diameters in length, and were all prepared in the laboratory, those to be frozen being exposed in the molds as soon as possible, generally in about 15 minutes after adding water. More 
water was used in the mixing than is usually used in laboratory tests, the object being to get the mortar and concrete as near as possible to the consistency that is ordinarily used in practice. The exposed specimens were placed on the west side of the Engineering Laboratory, where they were subjected to all of the changes of temperature and to the afternoon sun. The blocks were all made on the 9th, Ioth and IIth of February, during the extremely cold weather of the year 1899 , when the temperature during the day time averaged from 4 to 10 degrees: below zero, and at night went as low as from 16 to 24 degrees below zezo. No attempt was made to protect the green mortar and concrete other than the protection afforded by the molds, which were removed in from 6 to 24 hours.

The molds used were made from sections of wooden pipes intended as a covering for large steam mains. These were split longitudinally into thirds and were circled by bands drawn up by draw bolts, which held them together similar to the manner in which the hoops hold the staves of a tank in place. The molds could easily be removed from the blocks by loosening the bands.

The exposed blocks were removed to the laboratory 24 hours before being broken, and those remaining in the laboratory were kept in water after 24 hours. In breaking the blocks they were set in a shallow box containing sand. On top of the blocks were placed several thicknesses of $2^{\prime \prime}$ soft white pine lumber with the grain at right angles, and directly beneath the pressure head of the machine was placed a heavy piece of flat iron about I' square and $I \mathrm{I} / 2^{\prime \prime}$ thick. This method of crushing was adopted in order that the specimens might adjust themselves comfortably as the pressure was applied and prevent concentration over a small area. A record of outdoor temperatures was made and a temperature chart constructed from thesc observations, the theremometer being read from 3 to 6 times a day up to the first part of April, after which date there was no very cold weather. The conditions were about as severe as are likely to be met in practice. The specimens were exposed immediately after they were made, and as will be seen from the temperature chart, fig 6 , were subjected to alternate freezing and thawing. 


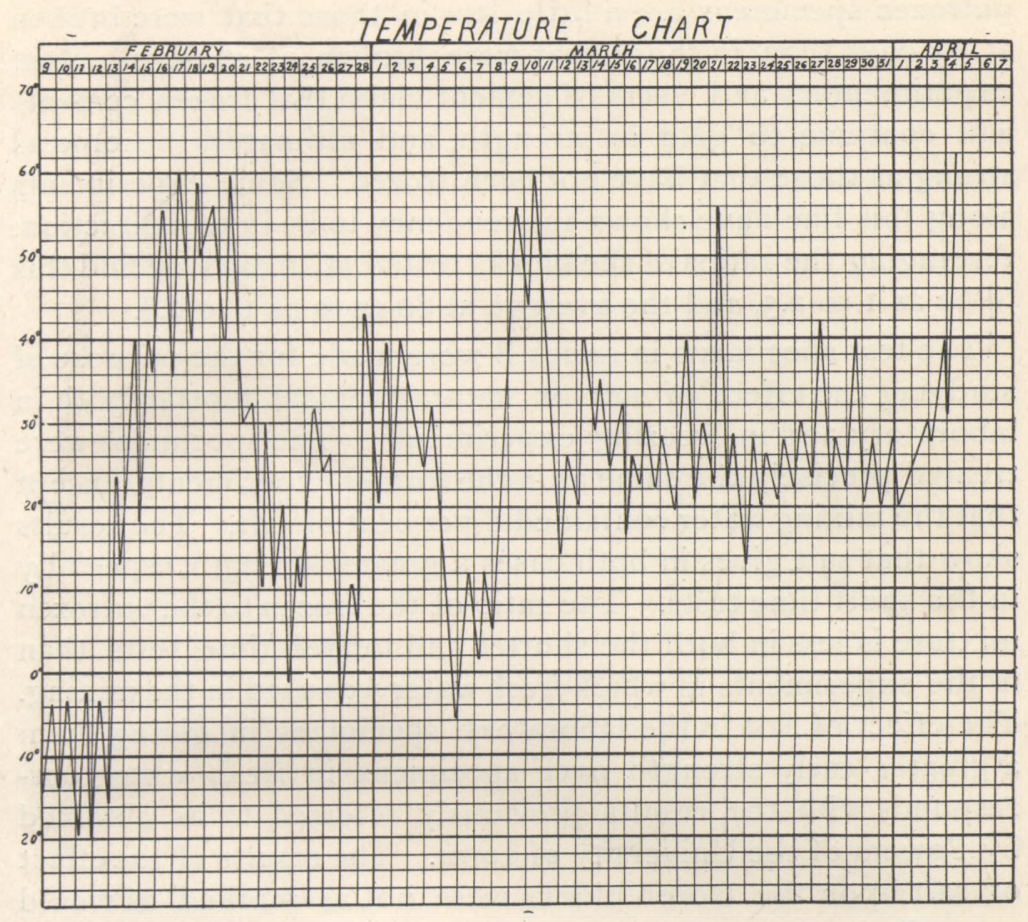

The mortar tests were made to study the effect of freezing upon natural cement mortar, both with and withont salt, the test specimens being prepared from Star brand of Louisville I part, sand 2 parts. The mortar was wetter than is usually the case in laboratory experiments, but not as wet as a mason usually wants his mortar. The results are shown in Table I, page $7 \mathrm{I}$.

In series A four blocks $4^{\prime \prime}$ in diameter and four blocks $6^{\prime \prime}$ in diameter were prepared. Two of each size were exposed in the molds as soon as made to an outside temperature of 7 degrees below zero, the remainder being kept in the laboratory for comparative results. The series of blocks in $A_{1}$ had precisely the same treatment as those in $A_{2}$, and the results seem to show conclusively that freezing does seriously affect the strength of mortars, under the above conditions. They also show that the ratios of the strengths of the frozen to the 
unfrozen specimens are a little less in those that were broken at 80 days than in those that were broken at 40 days. Most experimenters and users of cement claim that frozen cements will continue to gain in strength, and ultimately become as strong as those that have not been frozen. Some experiments along this line have shown the tendency to be in this direction. Averaging the ratios of the blocks tested at 40 days we find this to be as I to 2.3 , and the average at 80 days as I to 2.8 .

The test specimens in series B were made for the purpose of studying the effect of salt on natural cement mortar both in laboratory and in freezing experiments. The specimens were treated precisely the same as in the former experiments, except that the mixing water contained 8 per cent of salt. The results show that salt gives in both cases a greater strength, especially in the short time tests. The ratio of the frozen to the unfrozen mixture is less in both the shorter and longer time tests than in the experiments in which fresh water was used in the mixing. The effect of salt in the laboratory specimens in giving them a greater early strength over specimens in fresh water corresponds with the results previously referred to as obtained by Powers of the University of Iowa. The results of the effect of salt upon the frozen blocks were not as marked as would naturally be expected under these conditions.

The experiments upon concrete were of the same general character. Lägerdorfer portland cement was used, ordinary river sand and crushed limestone. The limestone was of such size as to pass a two inch ring, and included the crusher dust. The proportions were $1: 3: 6$, and were treated in the usual manner, the cement and sand being first mixed, water was then added before the dampened stone was incorporated. The whole was then thoroughly mixed and tamped into the molds. Upon removing the molds in series $\mathrm{C}_{1}$ it was found that the blocks were honey-combed at the surface. It was probably due to adding too much material at a time for it to ram well. The results show that the concrete was quite badly damaged by the freezing, the general ratio of frozen to unfrozen being I to 4.4 , which is a much greater loss of strength than in the mortar tests.

The blocks in series D were made to study the effect of salt 
on freezing concrete. A solution containing 4 per cent salt was used in the mixing water, and the green concrete was exposed to an exceptionally cold temperature, I6 degrees below zero. The results, when compared with those of the preceding two series, show that the salt helped the concrete. The blocks broken at 80 days show a healthy gain in strength over those broken at 40 days. The stone and sand used in these experiments had been in the laboratory for several months and were very dry. But it is generally the case in practice that the materials entering into concrete are at outdoor temperature and contain considerable moisture, so it was decided to try some experiments with broken stone and sand that had been exposed. The evening before the experiment the sand and stone were slightly dampened and placed outside of the laboratory window. The next day these materials were brought back into the laboratory and were made as soon as possible into concrete and again exposed. The pieces of broken stone were frozen together but contained no more moisture than exposed materials would ordinarily contain in this kind of weather. Of the blocks made from these materials series $\mathrm{E}$ was mixed with an 8 per cent solution, while the parallel series, $\mathrm{F}$, was mixed with fresh water. Otherwise the treatment was the same, and it will be noticed there is a great difference in the strength of the two mixtures, the concrete made with salt water showing a strength about 4 times as great as that mixed with fresh water. One peculiar thing in series E, is that the blocks broken at 80 days do not show a gain of strength, but even a small loss over those broken at 40 days.

The blocks in series $\mathrm{F}$ were the only ones that showed surface disintegration. A few days after they were made, cracks radiating from the center were observed on their ends; they gave a hollow and broken sound when tapped with the handle of a pen knife, and the surfaces scaled to some extent. Block No. 4 fell to pieces of its own weight. At the age of 40 days the upper third was badly crumbled. The pieces of broken stone from all of this series of blocks were clean, showing that adhesion did not take place between the mortar and the stone. The materials in series $\mathrm{E}$ and $\mathrm{F}$ were precisely the same with the exception that salt water was used in mixing the concrete 
in $\mathrm{E}$, and it will be noticed that series $\mathrm{E}$ gave a fair strength, while series $\mathrm{F}$ was worthless. The strength of the former can be attributed only to the salt, and we cannot help but conclude that salt is very beneficial, especially when the stone and sand are full of frost. Salt also shows a beneficial effect, both in strength and range, where the material is taken from the laboratory and exposed to freezing.

The conclusion to be drawn from the above, that salt is beneficial to cement exposed to freezing temperatures, is reached by practically all experimenters.

Tension tests of the same cement as that used in the concrete are given below. Two separate sets of briquettes of twenty each were made by two different operators. The proportions were I part Lägerdorfer cement and 3 parts sand. Ten of each set were placed out of doors immediately after being made, while the remaining ten were kept in water in the laboratory. The following are the average results of all the briquettes at an age of 37 days:

Frozen-Exposed from February 8 to April $16 \ldots \ldots \ldots$ I2 8 Unfrozen-One day in air, 36 days in water .......... I00

The exposed briquettes were placed on the East side of the laboratory and were layed directly on the ground where they could absorb moisture during each thaw, while all the blocks were placed on tarred paper. The changes of temperature, however, were very much less marked on the East side of the building and the afternoon sun could not reach the briquettes. To these differences and the different proportions of water used must be ascribed the chief causes for the above results.

Prof. Sims in reporting on the condition of the foundation and basement walls of the Collegiate building in the spring of I 900 said: "Some of this work was built while the theremometer ranged between 22 and 30 degrees, the stones having been exposed the night previous to temperatures as low as Io degrees, and were not heated. The mortar was made with hot water, to which salt was added, and was placed in the wall in much less time after tempering than was the case before the weather became cold. This doubtless is, to some extent, responsible for the fact that generally speaking the portions of the wall 
which were built in cold weather are as sound and strong as that built in the Summer and Fall. Some parts are showing surface disintegration and will have to be repointed, but there are no defects other than these which can be attributed to freezing."

From a consideration of the results of the tests and from all available data in regard to this subject, the following conclusions are offered:

I. Freezing injures both natural and portland cements under many of the conditions in which they are used in practice.

2. The injury may not be permanent and in time the frozen mortars or concretes may become as strong or stronger than those laid in warm weather.

3. Under the conditions met in practice salt is beneficial to cement used in freezing weather, especially if the materials are full of frost.

4. Hot water is more likely to injure cement exposed to freezing weather than to help it.

5. Natural cement should not be allowed to freeze where ice can form in contact with it until it is thoroughly hardened.

6. Portland cement stands alternate freezing and thawing better than natural cement.

7. In all cases, to avoid injury, cement should either be frozen before setting begins or should set and harden before freezing.

9. When frozen before it has set it should be prevented from thawing until it can remain thawed long enough to set and harden before again freezing.

Masonry work can be carried on in the winter weather with good results if proper precautions are taken. The brick, stone and sand must be free from ice and snow and should be thoroughly thawed out, but not made hot. Great care should be taken that no surplus water is left in the voids to freeze and disrupt if the work is likely to be frozen before it can set, for water is the destructive agent in cement work in winter time. In those cases where freezing before hardening is feared a minimum amount of water should be used, just enough for chemical combination. Many pieces of Winter laid masonry fail, and the failure is often attributed to the cement that has been used, whereas it has been produced by the expansion of 
the free water on becoming ice in partly hardened cement, thus breaking the crystals asunder by this mechanical action. Care should be taken with exposed masonry not to allow it to thaw out on one side, or unevenly, before the mortar has time to set and become reasonably hard. Unless this is done uneven settlement is likely to occur and cause disaster, as in the case of a stone water tower at Lena, Ill. In this particular case the upper 20 feet of the tower was laid during freezing weather. After the masonry had been in place about a week a warm beating rain thawed the mortar and washed it out on one side, and caused the destruction of the tower.

Numerous results point to the conclusion that if natural cement can be mixed with the right amount of water for these conditions and can be kept frozen until it has had time to set and harden, the strength is likely to be greater than if the same work were done in the Summer time. The effect of alternate freezing and thawing on recently laid natural cement mortar is to disintegrate a scale as deep as this freezing and thawing extends. Salt is beneficial from the fact that it lowers the freezing point of the water, and when frozen remains in a slush in the insterstices without a disrupting action. 


\begin{tabular}{|c|c|c|c|c|c|c|c|c|c|c|c|c|c|c|}
\hline & & & & & & & & & - & UNFI & ROZ. & FRO & $\mathrm{ZEN}$ & \\
\hline $\begin{array}{l}\text { Test } \\
\text { No. }\end{array}$ & Mixture & Object & $\begin{array}{l}\text { Date } \\
\text { Made }\end{array}$ & 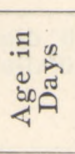 & 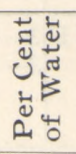 & 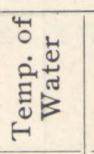 & ㅂ. & 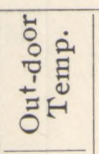 & $\begin{array}{l}\text { No. and } \\
\text { Size of } \\
\text { Blocks }\end{array}$ & 产家 & 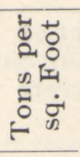 & 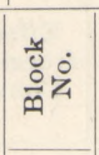 & 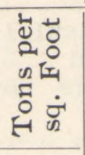 & $\begin{array}{l}\text { Ratio Froz. } \\
\text { to Unfroz. }\end{array}$ \\
\hline$A_{1}$ & $\begin{array}{ll}\text { Cement } & 1 \\
\text { Sand } & 2\end{array}$ & $\begin{array}{l}\text { Fffect of } \\
\text { Freezing } \\
\text { on Mortar }\end{array}$ & Feb. 9 & $\begin{array}{l}41 \\
41 \\
80 \\
80\end{array}$ & $*$ & $42^{\circ} \mathrm{F}$ & $57^{\circ} \mathrm{F}$ & $-7^{\circ} \mathrm{F}$ & $\begin{array}{l}4-4 " \text { diam. } \\
4-6 " \text { diam. }\end{array}$ & $\begin{array}{l}1\left(4^{\prime \prime}\right) \\
3\left(6^{\prime \prime}\right) \\
5\left(4^{\prime \prime}\right) \\
7\left(6^{\prime \prime}\right)\end{array}$ & $\begin{array}{l}13.4 \\
13.5 \\
39.5 \\
20.1\end{array}$ & $\begin{array}{l}2\left(4^{\prime \prime}\right) \\
4\left(6^{\prime \prime}\right) \\
6\left(4^{\prime \prime}\right) \\
8\left(6^{\prime \prime}\right)\end{array}$ & $\begin{array}{r}4.5 \\
6.6 \\
36.6 \\
6.3\end{array}$ & $\begin{array}{l}1: 3 . \\
1: 2 . \\
1: 1.1 \\
1: 3.2\end{array}$ \\
\hline $\mathrm{A}_{2}$ & $\begin{array}{ll}\text { Cement } & 1 \\
\text { Sand } & 2\end{array}$ & Same as $\mathrm{A}_{1}$ & Feb. 10 & $\begin{array}{l}40 \\
40 \\
80 \\
80\end{array}$ & * & $52^{\circ}$ & $54^{\circ}$ & $--10^{\circ}$ & $\left\{\begin{array}{l}4-4^{\prime \prime} \text { diam. } \\
4-6^{\prime \prime} \text { diam. }\end{array}\right.$ & $\begin{array}{l}1\left(4^{\prime \prime}\right) \\
3\left(6^{\prime \prime}\right) \\
5\left(4^{\prime \prime}\right) \\
7\left(6^{\prime \prime}\right)\end{array}$ & $\begin{array}{l}19.3 \\
16.2 \\
36.1 \\
16.2\end{array}$ & $\begin{array}{l}2\left(4^{\prime \prime}\right) \\
4\left(6^{\prime \prime}\right) \\
6\left(4^{\prime \prime}\right) \\
8\left(6^{\prime \prime}\right)\end{array}$ & $\begin{array}{r}4.6 \\
6.6 \\
11.7 \\
8.5\end{array}$ & $\begin{array}{l}1: 4.2 \\
1: 2.4 \dagger \\
1: 3.1 \\
1: 1.9+\end{array}$ \\
\hline B & $\begin{array}{l}\text { Cement } 1 \\
\text { Sand } 2 \\
\text { Salt } \\
4 \text { per cent }\end{array}$ & $\begin{array}{c}\text { Effect of } \\
\text { salt on froz- } \\
\text { en and un- } \\
\text { frozen mor- } \\
\text { tar. }\end{array}$ & Feb. 11 & $\begin{array}{l}40 \\
40 \\
80 \\
80 \\
80\end{array}$ & 19 & $69^{\circ}$ & $64^{\circ}$ & $10^{\circ}$ & $\begin{array}{l}6-4 \text { " diam. } \\
4-6 \text { " diam. }\end{array}$ & $\begin{array}{l}1\left(4^{\prime \prime}\right) \\
3\left(3^{\prime \prime}\right) \\
5\left(4^{\prime \prime}\right) \\
7\left(4^{\prime \prime}\right) \\
9\left(6^{\prime \prime}\right)\end{array}$ & $\begin{array}{l}14.3 \\
12.9 \\
47.8 \\
33.7 \\
13.8 \\
\end{array}$ & $\mid \begin{array}{rr}2 & \left(4^{\prime \prime}\right) \\
4 & \left(6^{\prime \prime}\right) \\
6 & \left(4^{\prime \prime}\right) \\
8\left(4^{\prime \prime}\right) \\
10\left(6^{\prime \prime}\right)\end{array}$ & $\begin{array}{r}8.6 \\
7.5 \\
22.0 \\
15.1\end{array}$ & 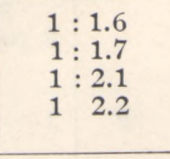 \\
\hline
\end{tabular}

Notes: Brand of Cement, Louisville Star. Kind of sand, River. Blocks to be frozen exposed within 15 minutes. "Mortar hardly as wet as ordinary mason's mortar, but too wet to ram well. Mortar in A2 not as wet as A1. †A, Nos. 4 and 8, defective in structure. 


\begin{tabular}{|c|c|c|c|c|c|c|c|c|c|c|c|c|c|c|}
\hline & & & & & & & & & & UNF & ROZ. & FRO & $\mathrm{ZEN}$ & \\
\hline $\begin{array}{l}\text { Test } \\
\text { No. }\end{array}$ & Mixture & Object & $\begin{array}{l}\text { Date } \\
\text { Made }\end{array}$ & 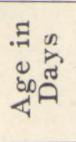 & 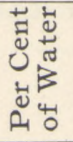 & 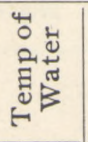 & 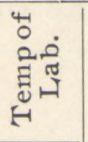 & 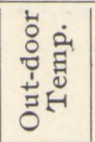 & $\begin{array}{l}\text { No. and } \\
\text { Size of } \\
\text { Blocks }\end{array}$ & 을 & 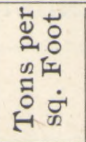 & 造它 & 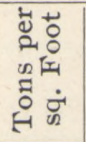 & $\begin{array}{l}\text { Ratio Froz. } \\
\text { to Unfroz. }\end{array}$ \\
\hline $\mathrm{C}_{1} *$ & $\begin{array}{ll}\text { Cement } & 1 \\
\text { Sand } & 3 \\
\text { Stone } & 6\end{array}$ & $\begin{array}{l}\text { Effect of } \\
\text { freezing on } \\
\text { Concrete }\end{array}$ & Feb. 10 & $\begin{array}{l}40 \\
40 \\
80 \\
80\end{array}$ & & $45^{\circ} \mathrm{F}$. & $57^{\circ} \mathrm{F}$ & $-2^{\circ} \mathrm{F}$ & $\begin{array}{l}3-8 \text { " diam. } \\
3--10^{\prime \prime} \text { diam. }\end{array}$ & $\mid \begin{array}{lr}1 & \left(8^{\prime \prime}\right) \\
3 & \left(10^{\prime \prime}\right) \\
5 & \left(8^{\prime \prime}\right) \\
6 & \left(10^{\prime \prime}\right)\end{array}$ & $\begin{array}{r}46.0 \\
9.8 \\
64.0 \\
66.8\end{array}$ & $\mid \begin{array}{lr}2 & \left(8^{\prime \prime}\right) \\
4 & \left(10^{\prime \prime}\right)\end{array}$ & $\begin{array}{r}14.7 \\
3.9\end{array}$ & $\begin{array}{l}1: 3.1 \\
1: 2.5\end{array}$ \\
\hline $\mathrm{C}_{2}$ & $1--3-6$ & Sameas $\mathcal{C}_{1}$ & Feb. 10 & $\begin{array}{l}40 \\
80 \\
80 \\
80\end{array}$ & & $45^{\circ}$ & $57^{\circ}$ & $-2^{\circ}$ & $\begin{array}{l}1-10^{\prime \prime} \text { diam } \\
2-\quad 8^{\prime \prime} \text { diam } \\
4-66^{\prime \prime} \text { diam }\end{array}$ & $\begin{array}{ll}1 & \left(6^{\prime \prime}\right) \\
3 & ( \\
5 & \left(6^{\prime \prime}\right) \\
5 & \left(8^{\prime \prime}\right)\end{array}$ & $\begin{array}{l}62.0 \\
44.9 \\
90.2\end{array}$ & 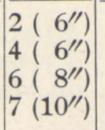 & $\begin{array}{r}7.6 \\
9.9 \\
24.9\end{array}$ & $\begin{array}{l}1: 8.1 \\
1: 4.5 \\
1: 3.6\end{array}$ \\
\hline D & $\begin{array}{c}1-3-6 \\
\text { Salt } \\
4 \text { per cent }\end{array}$ & $\begin{array}{c}\text { Effect of } \\
\text { salt on froz- } \\
\text { en concrete }\end{array}$ & Feb. 11 & $\begin{array}{l}40 \\
40 \\
80 \\
80\end{array}$ & 23 & $49^{\circ}$ & $54^{\circ}$ & $-16^{\circ}$ & $\begin{array}{l}2-8 \text { - diam. } \\
2-10^{\prime \prime} \text { diam. }\end{array}$ & & & \begin{tabular}{|rr}
1 & $\left(8^{\prime \prime}\right)$ \\
2 & $\left(10^{\prime \prime}\right)$ \\
3 & $\left(8^{\prime \prime}\right)$ \\
4 & $\left(10^{\prime \prime}\right)$
\end{tabular} & $\begin{array}{l}13.0 \\
13.8 \\
19.1 \\
15.1\end{array}$ & \\
\hline $\mathrm{E}$ & $\begin{array}{c}1-3-6 \\
\text { Salt } \\
8 \text { per cent }\end{array}$ & $\begin{array}{l}\text { Effect of froz. } \\
\text { stone and sand } \\
\text { with salt on } \\
\text { concrete }\end{array}$ & Feb. 11 & $\begin{array}{l}40 \\
40 \\
80 \\
80\end{array}$ & 25 & $48^{\circ}$ & $56^{\circ}$ & $-8^{\circ}$ & $\begin{array}{l}2-8^{\prime \prime} \text { diam. } \\
2-10^{\prime \prime} \text { diam. }\end{array}$ & & & $\begin{array}{lr}1 & \left(8^{\prime \prime}\right) \\
2 & \left(10^{\prime \prime}\right) \\
3 & \left(8^{\prime \prime}\right) \\
4 & \left(10^{\prime \prime}\right)\end{array}$ & $\begin{array}{l}17.9 \\
16.1 \\
14.1 \\
15.9\end{array}$ & \\
\hline$+F$ & $1-3-6$ & $\begin{array}{c}\text { Same as E } \\
\text { but without } \\
\text { salt }\end{array}$ & Feb. 11 & $\begin{array}{l}40 \\
40 \\
80 \\
80\end{array}$ & 25 & $48^{\circ}$ & $46^{\circ}$ & $-8^{\circ}$ & $\begin{array}{l}2-8^{\prime \prime} \text { diam. } \\
2-10^{\prime \prime} \text { diam. }\end{array}$ & & & $\left|\begin{array}{rr}1 & \left(8^{\prime \prime}\right) \\
2 & \left(10^{\prime \prime}\right) \\
3 & \left(8^{\prime \prime}\right) \\
4 & \left(10^{\prime \prime}\right)\end{array}\right|$ & $\begin{array}{l}5.7 \\
3.5 \\
4.2\end{array}$ & \\
\hline
\end{tabular}

Notes: Brand of cement, Lagerdorfer Portland. Kind of sand, River. Stone, crushed limestone, passing a 2 inch ring. * Blocks in $\mathrm{Cr}$ not as well rammed as in succeeding tests. tAfter crushing, the stones from series F were perfectly clean, showing lack of adhesion of mortar. 


\section{BIBLOGRAPHY.}

The following books, periodicals and articles were reviewed in the Engineering Library of the University of Iowa, and indicate the scope of the research:

\section{BOOKS REVIEWED.}

"Limes, Hydraulic Cements and Mortars," Gillmore.

" Hydraulic Cement," F. P. Spalding.

"American Cements," Uriah Cummings.

“"Masonry Construction," Prof. Baker.

"Materia1s of Construction," Prof. J. B. Johnson.

$$
\text { PERIODICALS REVIEWED. }
$$

Engineering News.

Engineering Record.

Engineering Magazine.

Municipal Engineering.

Trans. Am. Soc. Civil Engineers.

Jour. W. Soc. Engineers.

“Technograph," University of Illinois.

“Transit," University of Iowa.

Michigan Engineer's Annual.

\section{REFERENCES TO SPECIAL ARTICLES.}

"Report on Freezing of Mortars," Austrian Society of Engineers. The results are given of experiments made on full sized test walls. Eng. Rec., Vol. XXIX, p. 282; (Abstracts) Eng. News, Vo1. XXXIII, p. 282. Michigan Engineers' Annual for 1896, p. 203.

Editoria1, Eng. Rec., Vol. XXIX, p. 59.

Editoria1, Mun. Eng., Vol. X, p. 399.

"Effect of Salt Upon Freezing Mortars," Elliot C. Clarke, Trans. Am. Soc. C. E., Vol. XIV. p. 155.

"Effect of Frost Upon Portland Cement," Charles H. Godfrey; Eng. Rec., Vol. XXXIX, p. 75 .

"Effect of Freezing on Mortars," Alfred Noble; M. Am. Soc. C. E. Trans. Am. Soc. C. E., Vol. XVI, p. 79.

"Effect of Salt on Cement Mortar," M. I. Powers; the "Transit," University of Iowa, Vol. II, No. 1, Note; Abstract, Eng. News, Vol. XXVI, p. 481.

" Effect of Freezing Cement Mortar," A. C. Hobart; "Technograph," University of Illinois, No. XII, p. 67.

"Effect of Low Temperatures on Portland Cement Concrete," P. M. Bruner; Jour. Assoc. Eng. Soc., Vol. VII, p. 125.

"Frozen Concrete Pavement Foundations," Prof. L. Higgins; Eng. Rec., Vo1. XXXVII, p. 98.

"Effect of Freezing upon Cement," E. W. Muenscher, C. E; A very exhaustive article upon the literature of the subject. Michigan Engineers' Annual for 1896. 
“Effect of Freezing upon Mortars;" Eng., Vo1. X, p. 399.

"Cement versus Frost," C. B. Smith; M. Can. Soc. C. E. Jour. W. Soc. of Eng., Vo1. I, p. 681.

"Heating the Ingredients of Mortar," Wm. W. Maclay; Eng. News Vol. XXXIII, p. 282.

"Selection, Inspection, and Use of Cements,"' Jour. Assoc. Eng. Soc., Vo1. VII. p. 258, R. R. Gazette, Vol. XX, p. 754.

“'Tests of Frozen Cement Mortar," Arthur G. Fogg; Eng. Rec., Vo1. XXXIX, p. 79.

"Tests of Frozen Mortars in the form of beams,"' Barker \& Symonds, Dartmouth College; Eng. News, Vo1. XXXIII. p. 282, Abstract Michigan Engineers' Annual for 1896, p. 203.

"Use of Soda in Freezing Mortars," Eng. News, Vol. XXIV, p. 316, Vol. XXVI, p. 203, Vo1. XXIX, p. 146, Eng. Rec. Vol. XXVIII, p. 348, "Mixing Concrete in Cold Weather," Wm. H. Ward; Eng. News, Vol. XXXI, p. 181. 